\title{
Multivariable Functions of Savings and Credit in Menoua, West Cameroon
}

\section{Armand Gilbert NOULA}

\begin{abstract}
This survey attempts to scientifically examine Menoua Rural Populations' preoccupations, in the West of Cameroon, as far as the magnitude of supply of savings and the application for loans are concerned.

Considering Highly-varied available financial institutions in the area, potential customers weigh the optimum credibility likely to catalyze their choice, on the basis of the following assets: topmost security of deposits, confidentiality, free withdrawal of desired amounts when needs arise and facilitated loans lending process.
\end{abstract}

On the basis of data meticulously collected from the field and scientifically analyzed through two econometric models, namely the supply of savings and the application for loans, a close look at the socio-economic and demographic features, as regards a comparative dissection of facts, releases a genuine stratification of financial sectors, where transactions are commonly carried out.

Results obtained show that in the rural area, the fragmentation of the financial market and its extension to other socio-economic sectors enable each peasant to fully play his or her role, in the integration, on the process of comparative advantages. Menoua Rural Area in the West of Cameroon, -thanks to its dynamic spirit of Creativity and ingenuity, -has succeeded in forging a genuine and a really secure crisis exit!

The "NJANGI" or "TONTINE" System initiative has been developed, modernized and successfully transplanted as its ethics requires, on the entire Menoua geographical area and even beyond it, all over Cameroon. Although it is an apparently informal Financial Sector, "NJANGI" or "TONTINE" Groups are preferred to Modern Financial System, because they strictly respect the norms of local traditions. Peasants, at the time when they have to carry out their financial transactions, ought to make a really mature choice, according to their priorities and future achievements, aimed at, as targets.

From this analysis, the conclusion drawn is that, the Menoua Rural World, West Cameroon, in the end, use both Formal and Informal Financial Sectors. The movement of cash swings from the Modern Financial Sector to the Informal one, and vice versa, in specific circumstances, irrespective of the strata of populations, be they an educated folk or not. The supply of savings and applications for loans ostensibly change, depending on transactions. Any of both systems therefore has an intrinsic value! But, on top of these well recognized Channels, some peasants prefer saving rather in nature. Then, a clear disequilibrium is noticed between customers of formal financial institutions and those of informal financial ones.

Key words: Supply of Savings - Application for Loans - Econometric Approach - Menoua

\section{- Cameroon.}




\section{Introduction}

The exponentially speedy population growth in Sub-Saharan Africa has had to face productivity and chiefly poor level of savings, as compared to the smooth and constant rise in Formal Financial System, witnessed in developed countries. It is in this light that the World Bank in 1990, pointed out that, Population increase in Sub-Saharan Africa, requires the improvement of productivity, of instruments of growth and the raising of the level of savings.

Then, in order to achieve this goal, some strategic efforts ought to be made, so as to:

- generate more public savings while increasing incomes and decreasing expenditures simultaneously;

- increase and improve the mobilization of savings;

- insure mobilization of savings and an efficient allocation of financial resources (Papiel, 1994).

The absence of an efficient financial system is one of the facts and even the main cause of poor economic performances in most developing countries. This explains the reason why the role of mobilizing, allocating and controlling the use of funds is carried out by financial intermediation. In fact, in the rural zones, the financial system plays an important role in the spelling out of capital, growth in productivity, and consequently in economic development (Stiglitz, 1989).

The economic discrepancy observed, somehow catalysed by some inadvertent historical constraints, has compelled the rural populations in Menoua, West Cameroon, to look down the routine Formal Financial System and to appreciate the pragmatic and traditional Informal Financial Sectors. This sociological pragmatism has boosted the capacity of supply of loans from the easy flow in supply of savings, and the reasonable loans acquisition interest rates.

The spontaneous multiplicity of these informal set-ups, reinforced by the strength of traditions, has spread these informal financial institutions all over Menoua rural zones, making easy their closeness to the growing number of customers, ready to save their funds. Savings and loans lending, being the targets aimed at by these active rural populations, since they are always fond of building their future and that of their offspring, they entirely feel confident since this genuine creativity gives way to a thorough security of their deposits, transparency and confidentiality, as far transactions are concerned.

The present Research Work aims at displaying through a scientific scope, namely two econometric models, the ingenuity of these Menoua Rural Folks in the Western Province of Cameroon, a Sub-Group of the dynamic Bamileke tribe, at the heart of Central Africa. The comparative view of users keen on Formal Financial institutions and those preferring rather the informal Financial channels, enables to draw a sharp and convincing viewpoint at once. The ostentatious influence of the supply of savings and aspiration to loans acquisition, by non-financial parameters, wisely opens the gate to the reflexion as regards the restructuring of banking system policy in rural areas, in order to boost the vital function of savings and rural credit in Menoua, West Cameroon, instead of passively watching its continued dramatic regression. 


\section{Problem Statement}

According to the financial statistics of the IMF (International Monetary Fund) and BEAC (Central Africa States Bank), the cameroonian formal financial system is less developed, less varied, less efficient and is divided according to the formal financial system observed in developed countries (Bomda, 1998).

Thus, the M2/PIB (global money supply / gross domestic product) ratio which is an indicator of the level of financial development of a given country, dropped in Cameroon from 22\% in 1989 to 15\% in 1998. The reason of this fall is related to the adoption of the Structural Adjustment Program in 1988 by Cameroon. During the same period, the banking sector shrank and counted only seven banks in 1998 than twelve in 1989. This could be explained by the devaluation of the African Financial Community (CFA) Franc at $50 \%$ in 1994. Almost all bank accounts which were operational in rural zones had been closed down, though efforts are on the way to revive this sector. The combined effects of the adoption of the Structural Adjustment Program and the devaluation of the CFA Franc largely explain this disfunctionning of the Cameroonian financial system. This is the reason which may justify the dropping of the interior savings rate in Cameroon from 9\% in 1989 to 8\% in 1998. During the same period, public savings dropped from 190 billion CFA to 94 billion CFA while private savings fell from 317 billion in 1989 to less than 200 billion in 1998 (Noula, 2002). This decrease of the interior savings occurring with the reduction of the flow in foreign capital had as consequence, the reduction of credit to the economy. Hence in this process, rural zones were increasingly marginalized (Michael, 1997).

Formal financial institutions that would have encouraged the mobilization and allocation of rural financial resources were confronted with a certain number of constraints, mainly the high level of transactions costs, the insufficiency of information on needs, the preferences and the behaviour of customers and the lack of conventional guarantee, which obliged the Cameroonian rural populations to resort to the informal financial sector (Njangi (Communautary Mutual for Savings or Investments), usurers, parents, friends, etc) and the semi - informal sector (Cooperative and Mutual Savings and Credit Institutions, NGO (Non Governmental Organization), etc) (Alain \& Alii., 1991).

"NJANGI" or "TONTINE" is a sort of Informal Banking System where Funds are raised by a certain number of members, freely clubbed together. At each formal sitting or scheduled meeting, funds raised are ostentiously and solemnly handed to a given member, who is the expected beneficiary. Depending on the size of the enrolment, and the Internal Regulations, more than one member could gain at the same meeting. A Formal list of beneficiaries is made and released at the start, from a raffle draw, submitted to the whole audience, under their watchful eyes and in a strictly disciplinary context. When each member of the Group has gained, on the basis of this Formal agreed rotative list, another raffle draw is carried out, in order to come out with a new list for a following turn.

For the purpose of Group dynamism, the Club can opt for other strategies to stand as beneficiaries, and to give room to usury. The money gained by a member is the amount that he or she has raised throughout, for the one who benefits at the last position, or the amount he will raise in the end, for the cases of first beneficiaries. This capital is meant to be invested for positive fructification and never to be 
spent in an irresponsible manner. Active members of "Njangi" Clubs are ambitious people, and challenging developing agents. Internal Regulations are formally stringent and irresponsible people can never be admitted within such Clubs.

In addition to these constraints, there were the combined effects of the Structural Adjustment Program (1988) and those of the devaluation (1994) which made the functioning of the formal financial institutions out of place from the economic environment at the time.

In the past few years, the Cameroonian government faced a lot of difficulties in promoting financial institutions in the rural areas. Beside the policy of subsidizing interest rates, the rate of reimbursement was slow and the savings component was absent in almost all governmental credit programs (BelleSosso, 1997). The private semi-formal financial structures as the CAMCCUL (Cameroon Cooperative Credit Union League), the Afriland First Bank (Common Bank for Savings and Investment) led to important actions in the development of the rural financial system. However, much is still to be done for a better coverage of the rural zones of the country.

\section{Objectives of the Study}

We would like to put an emphasis on:

- The understanding of the supply of savings and application for loans by rural populations for the development of a rural financial system in accordance with their request (as their loans are concerned). This requires the restructuring of the banking system and the policy to watch over economic swings while controlling the main explanatory factors of the savings supply and application for loans.

- The mastering of the survey through the determination of the factors that influence the supply of savings and application for loans in the rural zones, and the assessment of the impact of these factors at the different informal and formal financial sectors in the Menoua administration in the West Cameroon. This choice is based on the availability of statistical data obtained through the identification and comparison of the rural farmers' preferences, the semi-formal financial institutions or financial services and finally recommended financial innovations that could contribute to the development of an efficient and lasting rural financial market in Cameroon.

\section{Hypotheses}

On the basis of the above objectives, the main research hypotheses are:

- The supply of savings and application for loans in rural zones are more influenced by "non financial" factors than by the interest rates. This encourages the variation of the effects of determinants of the supply of savings and application for loans from one financial sector to another, from one individual to another, and from one locality to another.

- The closeness of financial institutions to rural customers increases the supply of savings, the application for loans, and reduces the rate, thus encouraging rural farmers' preferences for financial services that are not homogeneous, although this may be different from those that financial institutions operating in rural zones could wish to offer. 
From these hypotheses, and on the basis of the statistical data collected from BEAC, the IMF, the Directorate of the Cameroon National Accounting Service and other local groupings, we will try to obtain our results from an econometric test, the explanatory factors of supply of savings and the application for loans existing in the rural areas of Cameroon.

\section{The Elements of Analysis MENOUA}

As one of the gate-ways into the Western Province of Cameroon, Menoua covers an area of about $1385 \mathrm{~km}^{2}$ on which about 380,000 souls hustle every day. It is a mountanous area that stretches from Mt Bamboutos slope in the North to "Mbo" plain in the South after an escarpment known as "falaise".

Two ethnic groups live in Menoua viz; the "Bamileké" of the plateau (much more populated indeed) and the "Mbo" in the plain (with inhabitants lightly scattered on the area).

From the administrative stand point, Menoua comprises 21 chiefdoms distributed in five sub-divisions viz: Dschang (Menoua's chief town), Nkong Ni, Penka Michel, Fokoué, and Santchou. Their population is mostly rural and live thank to the agricultural incomes.

They are characterized by their dynamism and their sense of development or progress, especially on the economic and social perspectives. In addition to the presence of a University in this Administrative Division which is a giant contributor to bank deposits, the population equally contributes to the bank deposits growth. The flourishing of savings and loan cooperatives in this Division is an on-going proof to justify the illustration of our survey. 


\section{GEOGRAPHICAL LOCATION OF MENOUA, WEST CAMEROON}

GEOGRAPHICAL LOCATION OF MENOUA DIVISION IN THE WEST PROVINCE

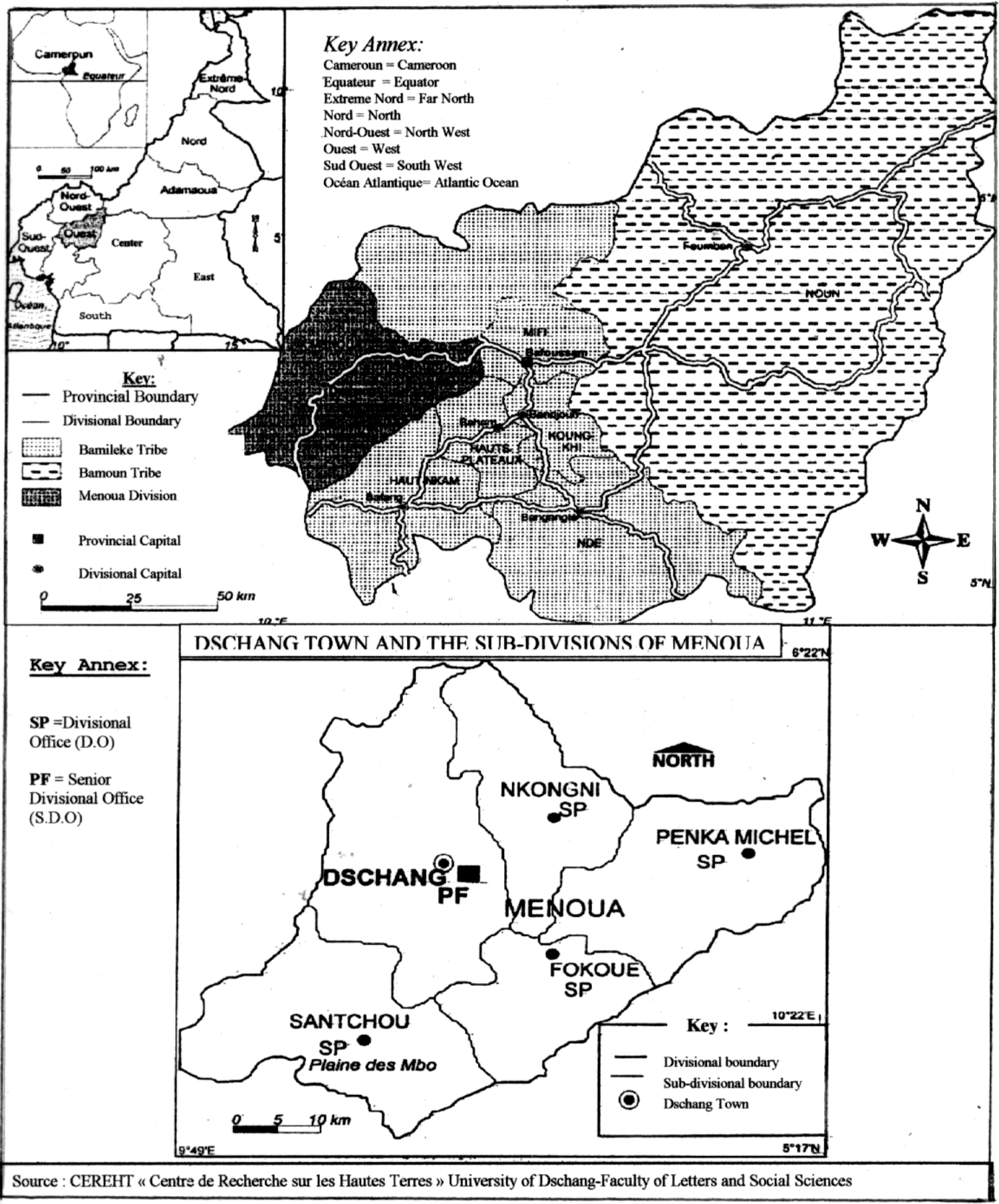




\section{Model}

To attain the objectives that we set up, data were collected from rural customers, financial institutions, and different developmental organisations operating in the rural areas of the West Province of Cameroon. In this study, different methods were used to analyse the data. Firstly, we will present the zone of investigation, the method of selection of samples and the different sources of data.

\section{Specification of Model}

On $Y_{i t}^{1}$ and $Y_{i t}^{2}$, the basis of literature and the informations collected on the field, two econometric models were specified and some variables chosen: one of the models concerns the supply of savings and the other, the application for loans. These models are as follows:

$$
\begin{aligned}
& Y_{i t}^{1}=f\left(X_{1 i}, X_{2 i}, S_{1 i}\right) \\
& Y_{i t}^{2}=f\left(X_{1 i}, X_{2 i}, S_{2 i}\right)
\end{aligned}
$$

where $Y_{i t}^{1}$ and $Y_{i t}^{2}$ represent the amount saved, and the amount of loans received by an individual $\mathrm{i}$ during the year $\mathrm{t}$.

$X_{1 i}$ is the vector of the socio-economic and demographic features of the individual $i$. The main features are; age, sex, level of education, family size, ratio of dependence, area of available land, cost of agricultural equipment, sources of income and the total annual incomes.

$\mathrm{X}_{2 \mathrm{i}}$ is the vector of the characteristics of the relationship between the individual $\mathrm{i}$ and the financial institutions considered; it is about the number and the type of financial institutions, the distance between the financial institutions and the place of residence, the duration of the relations, the costs of transaction carried out by the individual in his or her dealings with the institutions, the amount of credit received in year $\mathrm{t}-1$, the amount of savings made in year $\mathrm{t}-1$ and year t respectively and the frequency of the deposits.

The vectors of the characteristics of the financial institutions used by the individual i for the supply of savings and application for loans are $S_{1 i}$ and $S_{2 i}$ respectively. These characteristics are interest rates on the savings or on the credit, transparency, liquidity, discretion or confidentiality of the transactions and the security of funds.

In so far as two big financial sectors exist (informal and formal) in the rural environment, we will make a comparative survey of the effects of the vectors chosen. In this light, a stratification is made on the basis of the type of financial sector in which financial transactions are done. This stratification will enable us to divide the sample at the beginning into two sub-samples: i) the users of informal financial institutions; ii) the users of formal financial institutions.

\section{Estimation Method}

From 24 cases studied by Desai and Mellor (1993) ten were on the determinants of the supply of rural savings and fourteen on the determinants of the application for rural loans, twenty cases used the ordinary least-squares method to estimate parameters in specified models, while only four cases used 
the multiple regression analysis. The authors noticed that unique equation models will be preponderant because they require less data or because they do not need spontaneous adjustment hypothesis postulated in the simultaneous equation systems. More so, such a hypothesis, does not hold so far as the rural financial market is typically imperfect. Elsewhere, Maddala (1992) has underlined that when the stratification is done from one exogenous variable (here the financial sector in which the customer saves his or her money and carries out credits operations) like in the framework of our study, the model can be estimated from the ordinary least-squares method without any prejudice. Considering all this, the ordinary least-squares method seems to be the most appropriate to estimate parameters of the above mentioned specified model.

\section{Data}

The West Cameroon was selected because of the large number and the diversity of financial institutions and economic activities which exist in its rural zones. In fact, "Njangi" or "tontines" organisations in this Province fit as a genuine spirit of the custom of the populations and nearly every adult living in the rural zone is a member of one Njangi or one savings or credit association. "Njangi" in Cameroon is believed to have started from this Province and then extended to the whole country as the emigrating urge of the natives is high (Nzemen, 1993). A survey of the informal financial system in the Province, permitted a better understanding of the origins or foundation of "Njangi" movements in Cameroon and some of the factors that influence the behaviour of the actors of that system.

From the interviews and working sessions that were conducted with the leaders of the Provincial Delegation of Agriculture for the West Province, the FIMAC Program (Financing of the Agricultural and Communal Micro-Realizations), the National Project of Extension and Agricultural Research, of the banks (Afriland First Bank and Agricultural Credit of Cameroon), Cooperatives of Savings and Credit, four administrative divisions (Bamboutos, Hauts Plateaux, Menoua and Mifi) among the eight which make up the West Province, presented different types of financial institutions operating in that Province. From these administrative divisions, we have chosen Menoua for reasons of research costs and availability of data. This choice is a sample which covers different types of financial institutions found in this Division. The villages chosen are essentially of the Bamileke origin, which permits us to have a homogeneous population on the basis of socio-cultural trends.

Enquiries from rural customers aimed at collecting data were based on the activities of peasants, their financial transactions with different financial institutions, their needs and preferences concerning financial services. The choice of persons taken from each village was on the basis of an established peasants list by the National Agricultural Extension Project.

Our work has been facilitated by the fact that most individuals in our sample had undergone a somewhat similar investigation in 1995 (Bomda, 1998). The distribution of people interviewed in the villages and the type of inquiry are presented as follows: 
Table 1: Data

\begin{tabular}{|l|l|c|c|}
\hline District & Village & \multicolumn{2}{|l|}{ Number of persons interviewed. } \\
\hline & & By Questionnaire & By Choice of Combination \\
\hline Nkong Ni & Bafou & 60 & 50 \\
\hline Penka Michel & Penka Michel & 20 & 20 \\
\hline Penka Michel & Bansoa & 20 & 20 \\
\hline
\end{tabular}

The collection of data for informal financial institutions was geared towards the understanding of the objectives, strategies and operation models of these institutions. It was equally necessary to assess the supply constraints, thus the preference of these institutions in issues of financial services supply.

The selection of these institutions was carried out together with rural customers because the study was mainly about investigating the institutions with which the individuals and groups deal with their financial transactions. Thus, after the first phase of investigation, a list of informal institutions was established. Following this procedure, 10 among 85 financial institutions were chosen.

This operation of data collection took place twice: firstly in the month of September 1999 and secondly in December 2000. The Divisional Coordinators of the FIMAC program, thanks to their experience in the domain of rural financing, were instrumental in the survey.

We had been supplied with some secondary data by some Responsible Officials of the West Province, notably those of BEAC, Afriland First Bank, Cooperatives of Savings and Credit, Post Office Bank of Cameroon, the $\mathrm{MC}^{2}$ (Communautary Mutual for Growth) bilateral and multilateral Organizations (World Bank, GTZ (German Society for Technical Cooperation), CFD (Caisse Française Pour le Développement ), FAO (Food and Agriculture Organisation)) auxiliary divisional services for rural development.

\section{Results and Interpretations}

The chosen variables permitted on the one hand to compare savers and borrowers (in terms of financial sector), and on the other hand, to compare savings and credit transactions. Two financial sectors have been considered, viz; the FFS (Formal Financial Sector) and the IFS (Informal Financial Sector). In some cases, the banking sub-sector which is a part of the formal financial sector, is analysed in order to bring out its specific features. Considering credit transactions, the formal financial sector is not analysed simply because none of the people interviewed declared to have received any credit from this sector.

\section{Variables}

The explanatory variables of the models of rural savings supply and application for loans have been especially chosen on the basis of our objectives, literature review and among the factors of three main 
centres of interest: the socio-economic and demographic characteristics of the customers, the financial institutions and the characteristics of financial institutions.

The socio-economic and demographic features consist of age, sex, level of education, family size, ratio of dependence, available land surface, value of agricultural equipment, sources of income and income itself, and the Characteristics of relationships between the customers and the financial institutions.

1) The type and the number of financial institutions used by the customer;

2) The distance between the residence of the individual and the financial institutions, the duration of the business relationship between the customer and the financial institutions, the costs of transactions incurred by the customer, the amount of credit received by the customer in 1997/1998, the respective savings amounts in 1997/1998 and 1998/1999 and the frequency of the deposits. The characteristics of financial institutions consist of interest rate, transparency and liquidity of transactions, security of deposits and discretion or confidentiality in transactions.

Age is an important element of savings because of its impact on the individual's wealth history. Considering the life cycle hypothesis, the behaviour of household savings is determined by the level of goods to be acquired. Modigliani (1990) indicated that the aged group would be prepared to save more than the young one. One of the consequences of this report is that the application for loans decreases as age increases.

In the rural zones of most developing countries, men generally control goods and household incomes. They are most often responsible for cash crops and are more involved in large scale commercial business than women. Thus, it is possible to form the hypothesis that men save much higher amounts than women attempt to do. This hypothesis is equally valid for the application for loans as well as the involvement of men in more important activities could have entailed higher loan needs. The dummy sex variable which permits the analysis of the survey of this phenomenon takes the value 1 , when the customer is a man and the value 0 when the customer is a woman.

The level of education is important in explanation of peasants financial behaviour. In fact, it determines the place, the shape, and the volume of the financial characteristics (savings and credit). An educated person would be better informed of the existence of the different financial institutions and opportunities they offer than an uneducated one. He is well prepared to understand the procedures and the principles on which it works, to appreciate the earnings (such as positive interest rate, security of funds, etc...) and could therefore be able to better decide about what size of transactions to carry out with the institution. On the contrary, the non-educated individual will, to a certain extent, ignore the functioning principles and the opportunities that different institutions offer, and hence will be more sceptical with new types of financial institutions. This behaviour is likely to act negatively on the volume of his transactions with the institution. The level of education should thus affect either positively or negatively the supply of savings and application for loans of rural customers. A dummy variable is used in the survey; it takes the value 1 when the individual can read and write and the value 0 for the contrary case. 
The size of the family can be considered a measurement of initial wealth. Iqbal (1986) defends that a large family indicates a large dependence on the head of the family. This situation would negatively affect the rate of savings of the former. However, the family's needs can go beyond its financing capacity; that would cause him to have recourse to external financing. Hence, the bigger the family size is, the higher the application for loans would be. However, it should be noted here that the structure of the population was also identified as a factor influencing the behaviour of savings and application for loans in developing countries. Leff (1969) found an inverse relationship between the ratio of dependence and the rate of savings in developing countries. Thus, a large family, with a large number of persons aged between 15 to 64 years could have a high rate of savings in so far as they contribute to the increase in family income. However, this view has been criticized by authors like Bilsbarrow (1979) and Rossi (1989) on the methodological and theoretical approaches.

In this survey, the effect of the ratio of dependence on the supply of savings and application for loans in rural areas is analysed so as to draw concrete conclusions from the findings.

The available land surface here designates the surface appraised in acres of land which belong to customers. In the rural areas, this surface is often used as an indicator of wealth or of economic status. The individuals with large arable surfaces of land are supposed to have a large saving capacity because they can expect high agricultural income. Iqbal (1986) adds that although there is no prediction theory on the effect of the available land surface on the application for loans, even whether this relation would be negative. However, Ghate (1992) got a positive relationship between the two variables.

According to lqbal (1986), there is a positive link between the evolution of financial markets and the changes in agricultural techniques. On the one hand, the availability of funds would determine the rate of adoption of innovations, and on the other hand, the degree of technological changes would influence the application and the supply of credits. Thus, a strong rate of technological innovations would therefore increase the application for loans. In this survey, the value of agricultural equipment the interviewed owned, had been used to replace the rate of technical changes and its effects on the application for loans was analysed.

From Fischer's work (1989), we know that the level of income has a positive influence on savings, despite its effects on the ability and free will to save. The sources of these incomes are diversified; viz agriculture, breeding, small transformation of agricultural products, commerce, craftsmanship, gifts, etc. These sources influence the supply of savings on the basis of their profitability. Agriculture is generally known as a risky activity and less profitable than non-agricultural activities. If we agree with that statement, one is forced to think that the more the rural folk incline their incomes towards nonagricultural production, the more their volume of savings will be high and consequently their application for loans will be negatively influenced or will be low.

In the rural areas, an individual generally begins his savings transactions with an informal financial institutions. As for his socio-cultural and business contacts, his income and the information he receives increases, he will have the tendency to become a customer of several financial institutions. He won't 
probably quit certain financial institutions because of socio-cultural reasons, but will deal with others in order to be able to benefit from the opportunities that they do provide. This process, and therefore the number of financial institutions with which he does his financial transactions, will certainly affect his savings behaviour and his application for loans. But, it is difficult to predict the effects in different financial sectors.

The type of financial institutions used is also important in the financial behaviour of the peasants. Financial institutions present differences in their respective sectors about their status, procedures, the diversity and quality of services, etc. ... These particularities probably affect the behaviour of savings and that of the rural populations' application for loans. However, it is difficult to foresee the direction of this influence. In this survey, a dummy variable indicating the type of financial institutions used by the customer inside a given financial sector enabled the author to study this situation. Besides, location (distance) these financial institutions was also recognized as being one of the important institutional factors that influences savings in rural areas. When there are financial institutions in a village or its neighbourhood, rural populations save surpluses of their money in them (Padmanabhan, 1988) and also apply for loans to satisfy some of their needs.

The analysis of the duration of relationship between the customer and the financial institutions is important because, it enables one to appreciate the viability and the durability of the financial institutions used and their influence on the supply of savings and the application for loans in the rural areas. This variable can still be used to measure the extent to which customers trust their institution. The more people stay and participate together in certain socio-economic and financial activities, the more they benefit from cooperation and develop confidence among them and with their institutions, consequently the essentials of their transactions of savings and credit are attained. None would have any doubt about the positive effect of this variable.

The cost of transactions incurred by the customers include transport fares, charges on deposit expenses, photographs, pass books, etc. ... These costs reduce the level of interests paid on savings as well as the one coming from the activities financed by credit. These costs will certainly vary according to the total amount of savings and loans received. From this fact, one can state that the more the cost of transactions are high, the less customers will save and the less the quantity of applications for loans will be.

The extent to which loan facilities and savings are related has a very important role on rural savings (Vogel \& Burkett, 1986). This relationship encourages rural populations to deposit their savings in financial institutions in order to obtain loans. When the loan is granted to a member (or a customer) it is promptly and businesslikely invested in lucrative activities. This can increase his income and essentially his savings. In order to appreciate this phenomenon, we' ve analysed the impact of loans received in one year on the savings of the following year.

The frequency of deposits made by the customer in the course of the year is equally important in order to explain the savings behaviour of folks. It is admitted that regular collection of savings is a new way to 
synchronize the supply of savings to the flow of income in the rural areas (Padmanabhan, 1988). In this way, the more frequent deposits are collected, the higher the supply of savings is. In this sense, a better policy of mobilizing savings will stem from this fortunate contingency. Thanks to the supply of adapted financial services, the latter's effect will go to reduce the application for "liquidity credit". Since it is relevant to think that the more the amounts of savings made by the customer in year t-1 $(1997 / 1998)$ or in the year t (1998/1999) were high, the less was that of the credit in that year. Meanwhile, it is necessary to note that the hope/wish of a customer to obtain a credit depends highly on his savings deposit and capacity to constantly save, even if real interest rates are negative. In this case, the influence of savings on application for loans will be positive.

Confidence and incitations are the basis of all financial transactions (Heidhues, 1995) especially with the rural populations who are very careful when it comes to giving out their savings to others. Transparency, liquidity, security, discretion and even the level of interest rates are all factors which develop confidence and incite the increase of institutional savings (Padmanabhan, 1988).

In fact, the folks do not often appreciate procedures that are complex, non-transparent and long. And in the same way, the liquidity aspect itself, i.e to rapidly withdraw funds when one is in shortage of money, constitutes a vital need for the saver (Schmidt \& Kropp, 1988). The problems of liquidity which certain financial institutions present, might probably create distrust to the folks, and in this way, reduce from these institutions, their supply of savings. The security of deposits is the key factor considered by savers when choosing a specific financial institution and the amount to save absolutely depends on its being really sure that their funds will be safe.

Discretion is also an important factor in the explanation of financial behaviour of the rural populations. Nimal (1991) defended that in rural communities, people are used to application forms and procedures from time immemoral. These forms and procedures have become an integral part of their culture. When people are used to saving money in a discrete manner, the facilities that certain institutions offer and whose utilization is done to the knowledge of everybody, are not appropriate. We can in this way think that the more a customer estimates the level of discretion in his institution as being good, the more he will save.

The interest on the supply of savings and application for loans in rural areas still remains an open question. The effects of interest rates in the rural milieu, particularly found in Bomda's (1998) study, seem an ambiguous reason. Empirical estimations bring out results which run from very significant and positive effects to those with zero and insignificant effets. High interest rates favour financial savings as compared to non-financial savings that yield no interest at all (World Bank, 1996). The Bomda's (1998) study showed that the interest rate on loans is necessarily a determining factor for the application for loans by the rural population and that the application for loans is quite independent from interest rate. Belle-Sosso (1997) thinks that in developing countries the application for loans is elastic vis-à-vis the real interest rate, meanwhile the supply of rural savings arrives at, is in general non-elastic. Faced with this divergence, only an empirical analysis will permit one to reach some meaningful conclusions. 


\section{The Supply of Savings}

Among the retained variables, the author started eliminating at the first stage of the evaluation, all aberrant (unnecessary) exogenous variables. That means any variable whose impact on the supply of savings is nil, or not significant at a threshold of the degree of confidence less than $20 \%$.

At stage two, the models, where the test of Fisher Snedecor was used, released indications that all the estimated coefficients of independent variables were all nil or not significant to the $20 \%$ significant level.

Finally, at stage three, the author eliminated at the threshold of the degree of confidence less than $20 \%$, all models where the test of Durbin Watson showed that there is auto - correlation among residual terms.

At the end of these three steps and taking into consideration economic, statistical and econometric criteria, the model that caught more the writer's attention is the following one:

Table 2: Model of Savings Supply

\begin{tabular}{|c|c|c|c|c|}
\hline \multirow[b]{2}{*}{ Variables } & \multicolumn{2}{|l|}{ IFS } & \multicolumn{2}{|l|}{ FFS } \\
\hline & Coefficient & $T$ value & Coefficient & $T$ value \\
\hline Constant & $-2,500$ & $-1,205$ & $-1,500$ & $-0,489$ \\
\hline \multicolumn{5}{|c|}{ Socioeconomic and Demographic Features: } \\
\hline Age & $-0,654$ & $-1,940^{* *}$ & $+0,459$ & 0,617 \\
\hline Sex & $-0,840$ & $-3,110^{\star \star \star}$ & $-3,040$ & $-1,040$ \\
\hline Level of Education & $-0,684$ & $-0,978$ & $+0,980$ & 1,304 \\
\hline Size of the Family & $+0,237$ & $1,501^{*}$ & $-1,240$ & $-0,225$ \\
\hline Ratio of Dependence & $-0,690$ & $-0,283$ & $-3,080$ & $-2,158^{\star \star}$ \\
\hline Available Land Surface & $-0,384$ & $-0,347$ & $-1,015$ & $-0,881$ \\
\hline Source of Income & $+2,381$ & 1,905 & $+0,958$ & $1,998^{\star \star}$ \\
\hline Total income & $+0,854$ & 0,350 & $-1,730$ & $-1,445^{\star}$ \\
\hline \multicolumn{5}{|c|}{ Features of the Relations Between Customer and Financial Institutions } \\
\hline Numbers of IF Used & $+1,758$ & 0,589 & $-3,309$ & $-0,315$ \\
\hline Type of IF & $+1,015$ & $2,201^{\star *}$ & $+6,068$ & 0,856 \\
\hline Distance of the IF & $-1,162$ & $-0,040$ & $-2,222$ & $-2,999 * \star \star$ \\
\hline Duration of the Relations with the IF & $+0,245$ & $1,893^{\star}$ & $+3,342$ & $1,856^{*}$ \\
\hline Cost of Transactions with the IF & $-0,090$ & $-0,980$ & $-2,150$ & $-0,020$ \\
\hline Loan Received in $1997 / 1998$ & $+1,917$ & $2,380^{\star \star \star}$ & $+0,760$ & 0,180 \\
\hline Frequency of the Deposits & $+9,320$ & $1,660^{*}$ & $-0,345$ & $-0,930$ \\
\hline \multicolumn{5}{|l|}{ Features of Financial Institutions } \\
\hline Transparency of the Transactions & $-2,489$ & $-0,483$ & $+1,726$ & 1,005 \\
\hline Liquidity of the IF & $+6,320$ & $1,980^{\star *}$ & $-1,014$ & $-2,500^{\star \star}$ \\
\hline Security of Funds & $+1,020$ & 0,780 & $+2,384$ & $1,980^{*}$ \\
\hline Discretion in the Transactions & $+1,213$ & $3,450^{\star \star \star}$ & $+1,750$ & 0,890 \\
\hline Nominal Interest Rate & $-1,570$ & $-0,202$ & $+2,842$ & 0,784 \\
\hline $\mathrm{R}^{2}$ & \multicolumn{2}{|c|}{90,908} & \multicolumn{2}{|c|}{98,991} \\
\hline Adjusted $\mathrm{R}^{2}$ & \multicolumn{2}{|c|}{85,985} & \multicolumn{2}{|c|}{97,884} \\
\hline Durbin Watson & \multicolumn{2}{|c|}{$2,520^{\star \star \star}$} & \multicolumn{2}{|c|}{$2,043^{\star \star \star}$} \\
\hline $\mathrm{F}$ & \multicolumn{2}{|c|}{$234,000^{\star \star \star}$} & \multicolumn{2}{|c|}{$18,595^{\star \star \star}$} \\
\hline Number of Observations & \multicolumn{2}{|c|}{60} & \multicolumn{2}{|c|}{40} \\
\hline
\end{tabular}

N.B.: The signs $* * *, * \star$ and $*$ represent the levels of significance of $1 \%, 5 \%$ and $10 \%$, respectively.

From this Summary Chart (Noula, 2002) appears that the F (Fisher Snedecor) values are all significant. Thus, all the explanatory variables retained in different models, globally taken, significantly influence the supply of rural savings. In other words, it appears that all of them are neither nil nor significant at the threshold of the degree of confidence of $1 \%$. The values of the adjusted coefficient of determination $\left(R^{2}\right)$ 
allows the author to state that the utilized variables explained more than $85 \%$ of the supply of rural savings in the IFS (Informal Financial Sector) and more than $97 \%$ in the FFS (Formal Financial Sector).

From this Model, the coefficients sign of the variables as well as the Student Tests $(t)$ show that the effects of these variables on the supply of savings vary from one financial sector to another.

Concerning the socio-economic and demographic features, one can notice that the effect of age is significant in the IFS and its sign is negative. In the FFS, the coefficient has a positive sign, but is not significant. This seems to contradict the hypothesis of "life cycle" the author evoked above. However, some works by Heidhues \& Weinschenck (1989) showed that peasants often prefer saving in nature. From this fact, it would be possible to think that old people in rural areas, save important sums in nature and would not sufficiently trust in the different financial institutions.

The sex as factor is positive and meaningful as expected in IFS. In the FFS, it is negative and statistically not significant. The negative sign might indicate that men are less receptive and less active in the new financial institutions than women.

The effect of the level of education on the supply of rural savings is positive in the FFS and negative in the IFS. However, this effect is insignificant in any of these two financial sectors.

Results show that the bigger the family size is, the more the supply of savings in the IFS is and the reverse is completely true in FFS. This effect is significant in the IFS and the positive sign registered could be explained by the fact that when a large family includes a high proportion of persons aged from 15 to 64 years, its global income can be high and thus permits it to achieve important savings. The dependency ratio which permits the author to appreciate this phenomenon has a negative effect on the supply in all financial sectors, and it is significant in the FFS. This result does confirm Leff's study (1969) who thought that there is an inverse relationship between the dependency and the supply of rural savings in developing countries. Therefore, due to their inability to contribute towards production, a high proportion of people of less than 15 years and above 64 years, impose a constraint on the potentialities of the savings of the active population (from 15 to 64 years) by reducing their resources.

The effect on income is positive and significant as expected in the two financial sectors. This shows the interest to develop economic activities in rural areas. Through these activities, rural populations can increase their incomes, and therefore, their capacity to save in financial institutions. This could contribute to the development of a rural financial system. Indeed, the government and the donors should play an important role at this level through investments in support of projects, the development of infrastructures, the financing of literacy programs or education and training of peasants as well as the creation of a stable macro-economic environment that can encourage private institutions.

The influence on total income is positive and not significant in the IFS, negative and significant in the FFS. Thus, one can think that the more peasants obtain their incomes from non agricultural activities, the higher the volume of their savings in the IFS, and the reverse is true in FFS. The negative sign 
observed in the FFS is due to the fact that more often big farmers have important incomes and prefer to save in the FFS since they would obtain more security there (ceteris paribus ) and consequently benefit from other services like loans.

The effect on available land area is negative and not significant in all financial sectors. The negative sign might be explained by the fact that savers of the rural world obtain the most of their incomes or basic incomes, from breeding and perhaps from non-agricultural activities, for which the need of large areas of land is not indispensable.

Most factors that characterize the relationship between the customer and the financial institutions are essentially significant in the IFS. In fact these results indicate that the more the number of financial institutions with which the customer does his savings transactions and credit increases, the more the amount saved in the IFS increases and decreases in the FFS.

The effect of the FI (Financial Institutions) type utilized is positive in all financial sectors and is significant in the IFS. From this result, it can be said that the more the traditional mutual coffers and the $M C^{2}$ are used by rural populations, the more the volume of their savings increases. Even though the effect of this variable is not significant in the FFS, the amount saved tends to increase as the banks are used. Thus, some types of financial institutions present the characteristics that make people prefer them as compared to others like the traditional mutual offers which generally practise high interest rates, security, regular loans and are always available. Besides, $\mathrm{MC}^{2}$ offers security and discretion and facilitate the ties with other banks of commerce and the services of remittance from one locality to the other. This enables them to benefit from different opportunities offered by the financial markets. On the other hand, banks offer among others, remittance services, and the rural customers of these institutions can at least dream of getting loans one day. This actually is not possible with the other savings banks.

The analysis shows that distance has a negative influence on the amount saved as expected in the IFS, but it is not significant. This influence is negative and statistically significant contrary to expectations in the FFS. We think the more institutions are distant, the more rural customers acquire good discretion and therefore, be disposed to save high amounts. It would therefore be possible to think that the closeness of financial institutions provides adequate services (notably discretion, remittances, loans, etc. ...) and will have a positive influence on the savings of peasants. The analysis also shows that the effect of the duration of relationships between the customer and the institution is positive and significant. This means that the older a customer is in a financial institution, the more his savings may increase. Thus, the financial institutions durability would be an important factor for the mobilization of rural savings.

From the chart, one notices that the costs of transaction done by the customers have a negative influence but not significant on the supply of rural savings. Nevertheless, one can estimate that the higher these costs are, the less customers save. Some financial innovations would be necessary to reduce these costs. The effect of credit received in year t-1 (1997/98) has a positive and significant effect in the IFS. None of the people interviewed had received a loan from FFS the previous year. In 
fact, results show that this variable, although it is not significant in the FFS, it has a negative influence; which means that the more the customer receives loans from other financial sectors, the less he saves in the FFS.

The frequency of deposits, the last factor of the relationship between the customer and the financial institutions analyzed in this survey, has a positive and significant effect on the IFS. On the other hand, there is a negative sign in FFS due to the rhythm of investors' flow of incomes in this sector. In fact, among them are breeders and market-gardeners. Their level of income is generally high but comes only once or twice a year. So, these people would only make one or two important deposits per year.

From the analysis of the studied institutional factors, it comes out that transparency is not significant in any of the financial sectors. In fact, peasants think that transparency is implicitly witnessed in any of the financial institutions they belong to. This entails a weak variability of this factor in the econometric analysis.

As for the liquidity factor of the institutions, it has a positive and significant effect on the supply of savings in the IFS and a negative and significant effect in the FFS. This negative sign is probably due to the economic crisis that caused a dramatic liquidity shortage in the Cameroonian banking sector some time ago. In spite of this crisis, investors continue to save in this sector, so as to be fortunate to benefit from other services that are offered there.

Concerning the security of deposits, its influence is positive and not significant in the IFS whereas it is positive and significant in the FFS. These results show that when the amount to save is high, rural customers prefer the FFS.

The analysis of the discretion factor or confidentiality of the transactions shows that its influence is positive and significant in the IFS. This means that the more the investors observe that discretion in the institution is good, the higher the amount of savings is. On the contrary, this factor is not significant in the FFS. This is due to the fact that savers perceive discretion in the institutions as satisfactory from its weak variability. In order to explain the behaviour of savings in the IFS, the importance of the factor "discretion" allows us to think that if the institutions of FFS wish to increase their market shares, they must put in place facilities that offer confidence and institutions which treat the poor as precious customers (Engel \& Alii., 1993).

Finally, for interest rate, evaluations confirm the ambiguity of its effect on rural savings. In fact, its influence is not significant in any of the financial sectors and its sign is negative in the IFS whereas it is positive in the FFS. However, it would be difficult to deny the fact that high interest rates will probably have a positive effect on the supply of rural savings, at least, in the short term and later in the long run, because the rural financial market will develop, and competition will increase among different financial institutions.

Now, let's take an interest in the determinants of application for loans in rural zone. 


\section{Application for Loans}

Contrary to the previous analysis where two financial sectors were considered, the determinants of rural application for loans in the FFS won't be studied here for the reasons evoked earlier.

Following the same approach like the previous one, and taking into account the economic, statistical and econometric criteria, the model that drew our attention for the case of application for loans is presented as follow:

Table 3: Rural Application for Loans Model

\begin{tabular}{|c|c|c|}
\hline \multirow[t]{2}{*}{ Variables } & \multicolumn{2}{|l|}{ IFS } \\
\hline & Coefficient & Value of $t$ \\
\hline Constant & $+4,371$ & 0,059 \\
\hline \multicolumn{3}{|l|}{ Socioeconomic and Demographic Features } \\
\hline Age & $+8,045$ & $3,415^{\star \star \star}$ \\
\hline Sex & $-7,532$ & $-0,038$ \\
\hline Level of Education & $+8,706$ & $1,987 * \star$ \\
\hline Ratio of Dependence & $-8,536$ & $-0,784$ \\
\hline Available Land Surface & $-7,032$ & $-2,950^{\star \star \star}$ \\
\hline Agricultural Facilities & $+0,009$ & $6,237^{\star \star \star}$ \\
\hline Source of Income & $+4,258$ & 0,0524 \\
\hline Total income & $+0,245$ & $1,587^{*}$ \\
\hline \multicolumn{3}{|l|}{ Feature of the Relations Between the Customer and the FI } \\
\hline Type of FI & $-0,789$ & $-0,543$ \\
\hline Distance Between Customer and the FI & $-9,842$ & $-0,049$ \\
\hline Duration of the Relations with the FI & $+8,646$ & $1,996^{\star *}$ \\
\hline Cost of Transaction with the FI & $+3,867$ & 0,285 \\
\hline Savings in the Year (97/98) & $-0,486$ & $\mid-0,006$ \\
\hline Savings in the Year (98/99) & - & - \\
\hline \multicolumn{3}{|l|}{ Feature of the FI } \\
\hline Transparency of the Transactions & $+7,910$ & 0,475 \\
\hline Liquidity of the FI & $-9,43$ & $-2,500^{\star \star \star}$ \\
\hline Discretion in the Transactions & $+7,815$ & $3,845^{\star \star \star}$ \\
\hline Nominal Interest Rate & $-8,84$ & $-0,308$ \\
\hline $\mathbf{R}^{2}$ & \\
\hline Adjusted $\mathbf{R}^{2}$ & \multicolumn{2}{|c|}{$87 \%$} \\
\hline Durbin Watson & \multirow{2}{*}{\multicolumn{2}{|c|}{$\begin{array}{c}2,984 \\
5,245^{\star \star \star}\end{array}$}} \\
\hline & & \\
\hline Number of Observations & \multicolumn{2}{|c|}{$\begin{array}{c}5,245^{\star \star \star} \\
50\end{array}$} \\
\hline
\end{tabular}

N.B.: The signs $* * *, * \star$ and $*$ represent the levels of significance of $1 \%, 5 \%$ and $10 \%$, respectively.

Fisher Snedecor's value of $F$ is significant and permits to conclude that the variables of the model globally explains application for loans for the considered sample. Besides, the retained variables explain application for loans by $87 \%$. The somewhat low value of coefficient of determination $\left(\mathrm{R}^{2}\right)$, $70,9 \%$ shows that the model would not cover the most of the factors that explain the changes of application for loans. The factors not included would probably be socio-cultural ones that further studies shall try to identify.

Age is meaningful and its sign is positive. This means that the older the customer is, the greater his application for loans will be. One could deduce that aged people are more active as compared to younger ones. 
The sex factor is not significant, but from its sign, we think that the application for loans is lower with women than with men.

As for the level of education, it is significant and its sign is positive, indicating the application for loans increases with people's level of education. As seen previously, this result shows the necessity to set up education, training and literacy programs for rural populations.

The ratio of dependence is negative and not significant. It doesn't exclude the hypothesis that the application for loans is inversely related to the number of dependents.

The available land surface has a significant effect and has a negative sign. Thus, as the available land surface increases, the application for loans falls. This confirms the ambiguity of the effect of that factor on application for loans.

As for the effect of agricultural equipments, it is noted that the higher their values are, the more loans are applied for. This confirms Iqbal's results, and one sees the necessity to promote innovations in agriculture. However, it would be necessary to also ensure that the credits received by peasants actually permit them to improve their level of income.

The activity carried out by the customer (designated by the source of income) has a positive effect on application for loans. Although it is not significant, its sign makes one believes that the more a customer involves in other activities, the greater is his application for loans. As in the case of the supply of savings, this result reveals the necessity for financial institutions not to limit themselves solely in agriculture scope but to diversify their activities.

The effect of total income is positive and significant. This result is contrary to expectations and shows that people with high incomes can also have higher financial needs. This confirms Bomda's (1998) results. His suggestion as for the reason of the development of the rural zones, that it would be necessary to put an emphasis on economic activities because this will contribute to increase peasants' incomes and will have a positive effect on their capacity of indebtedness or credibility, was based on the positive sign.

About the characteristic effects of the relationship between customers and financial institutions, one can note that the type of financial institutions used in a given financial sector is not significant in the IFS. Thus, the fact that the credit comes from a Njangi, a traditional mutual coffer or a usurer, doesn' $t$ significantly influence the variation observed at the level of application for loans.

The influence of the distance on the application for loans confirms the situation observed in the analysis of its effect on the supply of rural savings. In fact, as the distance between the financial institutions and the customer increases, the more the application for loans decreases. On top of this, an increase would 
explain itself like in the case of supply of savings by the search among others for adequate services and discretion, that would be very important for customers of the formal financial institutions.

The effect of the duration of the relationship between the customer and the financial institutions is positive and statistically significant. Once more, this result shows the importance of the viability and the durability that should be taken into consideration in the rural financial institutions.

The influence of the costs of transaction to be incurred by the rural customers is positive but not significant. One can imagine that the financial institutions that are mostly young in the rural financial market, have costs of transactions that don't significantly affect the behaviour of their customers. Effectively, they must undertake the innovations that would permit them to reduce these costs as much as possible. So, the nearness of their structure to the communities, the reduction and the simplification of the procedures, as well as the ties with the informal structures, could be more useful.

The effect of savings made by the customer in the year 1997/1998 on the application for loans in $1998 / 1999$ is negative, indicating that the more the savings realised by the customer in a given year are, the less he will apply for loans the year after. This confirms Schmidt and Kropp's (1988) conclusions that a better mobilization of savings by a financial institution would have the effect of reducing application for loans.

Concerning the characteristics of financial institutions, the transparency factor is not significant since the liquidity of the financial institutions negatively and significantly influence the application for loans. This would mean that the more customers consider the availability of liquidity good, the less they apply for credit. This result somewhat is contrary to expectations, and quite difficult to explain. Nevertheless, this phenomenon could derive from the fact that, if the liquidity situation of a financial institution is found good, the members are going to make large deposits. And as the influence of savings in year t-1 (1997/1998) is negative, the application for loans for the following year will fall. It is therefore the indirect effect of the 1997/98 savings. This result confirms that Schmidt and Kropp (1988) supported the view that the rural populations' need for loans must be considered in line with savings need.

The positive and meaningful influence of the discretion factor shows that the more an institution offers confidentiality in its transactions, the more the application for loans will increase. It would thus be necessary that rural financial institutions, whose objective is to increase lending operations and to reach the maximum number of customers, put in place the facilities that offer discretion to customers and especially the values that are adequate with cultural realities. This view was supported by Bomda (1998).

Finally, the interest rate variable has a negative sign. Although it is not significant, one can imagine that the higher it is, the less customers ask for credit. This result confirms that of the informal financial institutions (Njangi, usurers, and traditional mutual coffers) which are perfectly integrated in the rural communities in which they are always ready for quick and flexible response to the urgent needs of rural 
customers. As a result, the interest rate doesn't seem to be an important determinant of the application for loans.

\section{Conclusion}

The survey analysis has shown that the determinants of the supply of savings and application for loans in rural areas vary from one financial sector to the other, thus confirming one of our main hypothesis. These differences contribute to the complexity and to the segmentation of the rural financial market in Cameroon.

The examination of the hypothesis related to the interest rates has proved that its effect on the supply of savings is not significant in any of the financial sectors. Concerning its effect on application for loans in rural areas, it is still not significant in the IFS.

The third hypothesis according to which the nearness of the financial institutions to rural customers increases the supply of savings and application for loans, has essentially been verified in the IFS. Thus, for a relaunch of a rural financial system that offers suitable and lasting services, the characteristics of the IFS that serves the majority of the populations in rural zones, mainly in West Cameroon, should be taken into account and some financial innovations ought to be undertaken on the basis of the main determinants of supply of savings and application for loans revealed by this study.

We can think that the financial institutions based in rural or nearby zones should innovate in order to reduce the costs of transactions imposed by investors and borrowers, by offering the continuity, the possibility of remittance, the security of funds and discretion. Indications as the tie between savings and loans and an optimum interest rate on loans should be able to considerably improve performances in the mobilization and the allocation of rural financial resources.

\section{Reference:}

Alain H. \& Alii. (1991): Tontines et banque au Cameroun; Ed. Karthala, Paris. Banglagesh : An Empirical Analysis. FCND Discussion Paper NO. 15, IFPRI.

Banque Mondiale (1990) : Financial Systems and Development. World Bank, Washington, D.C.

Banque Mondiale (1996) : Un peuple endurant dans un milieu hostile : Evaluation de la pauvreté au Niger. Département Afrique Centre-Ouest, Division de la Population et des Ressources Humaines, Washington, D.C.

Belle-Sosso D. (1997) : Analyse comparative des coûts de transaction des crédits de groupes et des crédits individuels des marchés financiers ruraux au Cameroun. Verlag Ulrich E., Grauer, Stuttgart.

Bilsbarrow R. (1979): Age Distribution and Savings Rates in Less Developed Countries. Economic Development and Cultural Change, vol.28, pp. 23-25.

Bomda J. (1998) : Déterminants de l'épargne et du crédit, et leurs implications pour le développement du système financier rural au Cameroun. Development Economics and Policy, Ed. by Franz Heidhues.

Desai B. M. \& Mellor J. W. (1993) : Institutional Finance for Agricultural Development: An Analytical Survey of Critical Issues. IFPRI, Washington, D.C.

Engel J. F. \& alii. (1993) : Consumer Behaviour. Seventh Edition, Fort Worth, TX, USA : The Dryden Press. 
Fischer B. (1989) : Savings Mobilization in Developing Countries : Bottlenecks and Reform Proposed. Savings and Development, vol.13, $N^{\circ} 2$.

Ghate P. B. (1992) : Interrelation Between the Formal and Informal Sectors : the Asian Experience. World Development, vol.20, nE6, pp.859-872.

Heidhues F. (1995) : Rural Financial Markets-An Important Tool to Fight Poverty. Quarterly Journal of International Agriculture, Vol.34, NO 2, pp. 105-108.

Heidhues F. \& Weinschenck G. (1989) : Cameroon Rural Finance Sector Study. Rural Finance Profile in Africa Countries, vol.2, Edited by Mario Massini for the FAO-FINAFRICA. Working Group, Milan.

Iqbal F. (1986): The Demand for Funds by Agricultural Households : Evidence from Rural India. Journal of Development Studies.

Leff N. (1969) : Dependency Rates and Savings Rates. American Economic Review, vol.59, pp. 886896

Maddala G. S. (1992) : Introduction in Econometrics. Macmillan, $2^{\text {nd }}$ Edition, New York.

Michael B. (1997) : Agricultural Price Policy and its Impact on Production, Income, Employment and the Adoption of Innovations. A Farming Systems Based Analysis of Cotton Policy in Northem Benin.

Modigliani (1990) : Savings in Mezzogirno of Italy. Journal of Regional Policy, vol. 10. NO1.

Nimal A. F. (1991) : Determinants of Rural Savings in Paqua New Guinea. Savings and Development, $N^{\circ} 4, X V$.

Noula A. G. (2000) : Les Déterminants de la demande de monnaie au Cameroun: Une approche par une fonction Cobb-Douglas. Revue Sciences Agronomiques et Développement, FASA Université de Dschang, pp. 38-62.

Noula A. G. (2002): An Analysis of Rural Savings in the Menoua Division of Cameroon. A Biannual Journal of Publication of the Faculty of Business. University of Botswana, pp. 8-26.

Nzemen M. (1993) : Tontine et développement ou le défi financier de l'Afrique. Presse Universitaire de Yaoundé, Cameroun.

Padmanabhan K. P. (1988) : Rural Credit : Lessons for Rural Bankers and Policy Makers. Intermediate Technology Publications, London.

Papiel Paul A. (1994) : Financial Systems in Sub-Saharan Africa. World Bank Discussion Papers 260, World Bank, Washington, D.C.

Rossi N. (1989): Dependency Rates and Private Savings Behaviour in Developing Countries. International Monetary Funds, Staff Papers, vol.36, pp.166-181.

Schmidt H. R. \& Kropp E. (1988) : Financement rural: Cadre d'orientation. Manuels de Développement Rural, GTZ, Eschborn, R.F.A.

Stiglitz J. E. (1989) : Incentives, Information, and Organizational Design. Empirica, Vol.16.

Vogel R. C. \& Burkett P. (1986) : Deposit Mobilization in Developing Countries : The Importance of Reciprocity in Lending. Journal of Developing Areas, vol.20, NO.2. 